УДК 930.2(437=161.2)"1920/921":[94(477):929Масарик(437)]

DOI: https://doi.org/10.31652/2411-2143-2020-34-92-99

\title{
Олександр Кравчук
}

Вінницький державний педагогічний університет імені Михайла Коцюбинського кандидат історичних наук, доцент (Україна) e-mail: ol-kravchuk@i.ua

ORCID: https://orcid.org/0000-0003-3504-5041

ResearcherID: M-6141-2018

\section{Т. Ґ. Масарик і українське питання у документах представництва Західноукраїнської Народної Республіки у Празі}

\begin{abstract}
Анотація. Мета статmі - проаналізувати повідомлення представництва зУНР у Празі про ставлення президента Чехословаччини Т. Ґ. Масарика до українського питання. Методологія дослідження грунтується на науково-дослідницьких принципах історизму, науковості, об'єктивності, загальних наукових методах (джерелознавчого аналізу, історичного і логічного) та спеціальних історичних методах (наративному та проблемнохронологічному). Наукова новизна роботи полягає у тому, що у статті на основі архівних $i$ опублікованих матеріалів, зокрема, листів голів представництва Західноукраїнської Народної Республіки у Празі до керівників зовнішньополітичного відомства зазначеного державного утворення, аналізується ставлення першого президента Чехословаччини до українського питання. Висновки. Ставлення Т. Г. Масарика до українського питання розглядається у контексті встановлення відносин між Чехословаччиною і Західноукраїнською Народною Республікою наприкінці 1918 - на початку 1919 рр., прагнення представників останньої у 1920-1923 рр. здобути підтримку Праги у забезпеченні визнання країнами Антанти самостійності иієї держави, обговорення справи допомоги українським емігрантам у ЧСР. Відзначено зміни позиції президента ЧСР в українському питанні. У праці «Нова Європа» (1918 р.) він підтримував ідею об'єднання Наддніпрянщини, Східної Галичини та Буковини в єдину українську автономію та перебування ї̈ у складі фредеративної демократичної російської держави. На початку 1919 р. президент чСР був готовий визнати незалежність Української Народної Республіки, яка відродилася під час протигетьманського повстання. Але остаточне рішення він ставив у залежність від позиції держав Антанти на мирній конфреренції у Парижі. Висвітлення представниками ЗУНР в Празі сприйняття українського питання Т. Г. Масариком у 1920-1921 рр. свідчить про його повернення до концепції, викладеної у праці «Нова Європа». Повідомлення представників ЗУНР дозволяють більш повно вивчити обставини, що унеможливили здобуття нею політичної підтримки з боку Чехословаччини. Враховуючи це, а також порушені у звітах представництва питання політики чСР в Закарпатті та щодо еміграції, зазначені документи є важливим джерелом вивчення історії чехословацько-українських відносин.
\end{abstract}

Ключові слова: дипломатія, емігранти, Є. Левицький, Є. Петрушевич, Закарпаття, Західноукраїнська Народна Республіка, С. Смаль-Стоцький, Т. Г. Масарик, Чехословацька республіка.

Постановка проблеми. Одним із пріоритетів сучасної вітчизняної історичної науки $€$ дослідження зовнішньополітичної діяльності українських державних утворень часів революції 1917-1921 рр. Значна увага їх дипломатичних представництв зосереджувалася на аналізі ставлення до України лідерів сусідніх країн. У цьому контексті важливим історичним джерелом $€$ дипломатична документація представництва ЗУНР у Празі про позицію першого президента Чехословацької республіки Т. Ґ. Масарика щодо політичних перспектив розв'язання українського питання.

Мета статті - проаналізувати повідомлення представництва ЗУНР у Празі про ставлення президента Чехословаччини Т. Ґ. Масарика до українського питання.

Аналіз джерел та останніх досліджень. Важливість теми обумовлюється також відсутністю відповідних спеціальних досліджень в історіографії, незважаючи на висвітлення окремих аспектів відносин ЧСР і ЗУНР у низці праць (Бетлій, 2006; Віднянський, 1997; ГалицькаДідух, 2015; Гарбульова, 2013; Кірсенко, 2006; Литвин, 2012; Нагорняк, 2000; Павлишин, 2013; Павлюк, 1997 та інші).

Основним джерелом статті стало дипломатичне листування голів представництва ЗУНР у Празі С. Смаль-Стоцького і $Є$. Левицького з Уповноваженим для закордонних справ у серпні 1920 - січні 1921 рр. - С. Витвицьким і у січні 1921 - лютому 1923 рр. - К. Левицьким. Листи зберігаються у фонді «Представництво Західно-Української Народної Республіки в Празі» 
Центрального державного архіву вищих органів влади і управління України у м. Києві [ЦДАВО України. Ф. 4440. Оп. 1. Спр. 15. Арк. 1-95; Спр. 16. Арк. 1-249]. Частина листів опублікована у збірнику документів і матеріалів з історії цієї держави [Західно-Українська Народна Республіка 1918-1923, 2001, 2008, 2011]. У листах погляди Т. Ґ. Масарика згадуються у контексті розмов С. Смаль-Стоцького з діячами ЧСР у вересні 1920-січні 1921 рр., зокрема, з міністром закордонних справ Е. Бенешем, особистим секретарем президента Чехословаччини В. Шкрахом, працівником Канцелярії президента ЧСР, референтом у справах Підкарпатської Русі (офіційна назва Закарпаття у складі ЧСР) Я. Нечасом. Також у статті використано інші українські та чеські документальні видання [Піскун, 2016; Топінка, 2010; Doubek, 2016; Hájkova, Quagliatová \& Vašek, 2013]. У статті документи ЗУНР цитуються мовою оригіналу, із збереженням орфографрічних особливостей тексту.

Виклад основного матеріалу. Встановлення і розвиток дипломатичних відносин з сусідньою Чехословацькою республікою належали до пріоритетів зовнішньої політики ЗУНР. Як союзна держава країн Антанти, Чехословаччина мала змогу підтримати перед ними визнання незалежності ЗУНР [Павлюк, 1997: 115, 118]. Для західноукраїнських політиків значення Чехословаччини збільшилося після згоди Праги на інтернування у ЧСР у 1919-1920рр. підрозділів Української Галицької армії чисельністю 11 тис. осіб [Карпенко, 2011: 110].

Перші контакти представників ЧСР і ЗУНР відбулися наприкінці 1918 р. - на початку 1919 р. 13 грудня 1918 р. голова Української національної ради Західноукраїнської народної республіки $€$. Петрушевич призначив С. Смаль-Стоцького на посаду «представника Зах. У.Н.Р. до Праги». Це неприхильно сприйняв тодішній прем'єр-міністр ЧСР К. Крамарж, який виступав проти публікації у пресі Чехословаччини матеріалів про Україну [Карпенко, 2011: 102; ЦДАВО України. Ф. 4440. Оп. 1. Спр. 16. Арк. 76]. С. Смаль-Стоцький пояснював позицію К. Крамаржа русофрільськими настроями чеського суспільства, яке самостійницькі змагання українців вважали «зрадою» слов'янства, «інтриґою австрійською, габсбурзькою і німецькою» [ЦДАВО України. Ф. 4440. Оп. 1. Спр. 16. Арк. 76].

Іншим було ставлення президента ЧСР Т. Ґ. Масарика, який був одним з небагатьох державних лідерів міжвоєнної Європи, знайомих із українським питанням [Григориїв, 1941: 2]. Відродження УНР під час протигетьманського повстання скоригувало концепцію президента в українському питанні. У праці «Нова Європа. Слов'янська точка зору» (1918р.) він висловився за об'єднання Східної Галичини, Буковини та Наддніпрянської України в автономне утворення у складі демократичної російської федерації [Віднянський, 1997: 47]. Але на початку 1919 р. президент дещо змінив свої погляди, був готовий визнати незалежність УНР. Президент ЧСР Т. Ґ. Масарик, на аудієнції у якого С. Смаль-Стоцький був 2 січня 1919 р., позитивно поставився до утворення представництва ЗУНР, а незабаром - місії УНР. Тоді ж Т. Ґ. Масарик зауважував Е. Бенешу необхідність мати чехословацьких представників в Києві [Hájkova, Quagliatová \& Vašek, 2013: 60]. Водночас, президент, за спогадами О. І. Бочковського, стосовно «перспектив українського питання у найближчому часі ... гадав, що це буде справа мирової конференції, яка має її вирішити. ... » [Бочковський, 1930: 14].

Після об'єднання українських держав та розгортання діяльності Надзвичайної дипломатичної місії УНР у Празі на чолі з М. Славінським, С. Смаль-Стоцький працював у ній [Карпенко, 2011: 102].

Про доброзичливе ставлення Т. Ґ. Масарика до України свідчить відвідування Праги наприкінці лютого 1919 р. спеціально уповноваженим послом уряду УНР, заступником міністра закордонних справ Л. Цегельським [Цегельський, 1960: 305]. Про результати своєї місії і, зокрема, про аудієнцію у Т. Ґ. Масарика з М. Славінським, Л. Цегельський доповів на засіданні уряду Західної області УНР 20 березня 1919 р. На переконання Л. Цегельського, «Думкою Масарика і Бенеша, а тим самим і чеської держави $€$ конечність сотворення української самостійної держави» [Карпенко, 2001: 88]. Також про про певні зміни поглядів президента щодо українського питання свідчить його лист Е. Бенешу 30 квітня 1919 р., де він, зокрема, писав: « ... Росія розпалася, і тому на часі організація цих окраїн $є$ краща, ніж розпад під моск[овським] невмілим централізмом! Тому ми ... беремо до уваги status quo» [Hájkova, Quagliatová \& Vašek, 2013: 129].

Сучасний дослідник М. Нагорняк зауважував, що незалежна Україна як безпосередній сусід Чехословаччини «видавалась останній вигіднішим партнером у реалізації слов'янської ідеї, ніж більшовицька Росія» [Нагорняк, 2000: 279]. Але події в Україні, починаючи з другої половини 1919 р. унеможливили розвиток відносин між УНР і ЧСР у такому напрямі. Директорія УНР на чолі з С. Петлюрою взяла курс на подальше відстоювання державності у союзі 3 Польщею. Натомість західноукраїнські політики в еміграції віддали перевагу пропаганді ідеї незалежної нейтральної Галицької республіки під протекторатом Ліги Націй [Галицька-Дідух, 2015: 38]. Для цього 25 липня 1920 р. Є. Петрушевич утворив «Уряд Диктатора ЗУНР» у Відні та низку дипломатичних представництв [Павлюк, 1997: 128]. 
Представництво ЗУНР у Празі отримало фінансування з 1 вересня 1920 р. Його офіційна назва - Дипломатична Місія Західно-Української Народної Республіки в Празі. Тимчасовим головою представництва призначено С. Смаль-Стоцького, а з вересня 1921 р. - Є. Левицького [Карпенко, 2001: 590]. Можливо, при цьому враховувалася та обставина, що обоє, як і Т.ґ. Масарик за часів Австро-Угорщини, були депутатами парламенту Ціслейтанії [Історичні постаті Галичини XIX - XX ст., 1961: 234].

Ставлення Т. Ґ. Масарика до українського питання і загалом офріційна позиція ЧСР в умовах, які змінилися, розкрита С. Смаль-Стоцьким у донесеннях до Уповноваженого для закордонних справ у вересні 1920 - лютому 1921 рр.

Звітуючи про візит до Е. Бенеша 13 вересня 1920 р., С. Смаль-Стоцький повідомив про обговорення справи Галичини, ідею самостійності якої він відстоював. Прикметно, що С. СмальСтоцький говорив і про можливість приєднання ЗУНР до військово-політичного союзу Мала Антанта, у яком вбачав «зародок союза слов'янського». Е. Бенеш зауважив, що цей союз утворено, насамперед, для втілення у життя мирних договорів, які стосуються його учасників. На думку С. Смаль-Стоцького, Е. Бенеш не очікував успішного завершення мирних переговорів у Ризі та вважав доцільним скликання нової конференції «всіх народів сходу Європи або влад, які повстали в революції, де і Чехословаччина була-б заступлена», а ії ініціатором міг би стати Т.ґ. Масарик. Водночас С. Смаль-Стоцький вказував на загальний характер цієї ідеї. Також представник ЗУНР відзначав підтримку чехословацькою владою української еміграції [Карпенко, 2011: 168-173].

У повідомленнях С. Смаль-Стоцького фріксувався інтерес чехословацьких політиків до України як до єдиної держави. Про це, зокрема, йшлося у повідомленні представника ЗУНР про візит 5 жовтня 1920 р. до В. Шкраха. С. Смаль-Стоцький зауважив його прагматичний ентузіазм щодо єдиної України, вступ якої до Малої Антанти міг би посилити цей союз, довівши чисельність населення його країн-учасниць до $80 \mathrm{mлн.} \mathrm{осіб.} \mathrm{В.} \mathrm{Шрах} \mathrm{також} \mathrm{наголошував} \mathrm{на}$ необхідності спільних дій українських політиків «з одною-одинокою метою на умі, аби була Україна ... ». У тій же розмові дипломат дізнався, що незабаром до Праги приїде В. Винниченко, який мав відвідати Т. Ґ. Масарика [Карпенко, 2011: 232-234].

С. Смаль-Стоцький також доповідав про зустріч 8 листопада 1920 р. президента ЧСР 3 дипломатом УНР О. Шульгиним, який прямував до Женеви [Топінка, 2010: 73]. Зауважувалося, що О. Шульгина «надзвичайно сердечно» прийняли в Граді: «Масарик сказав, що він переконав ся, що Радянська Україна се дійсна інвазія російських большевиків, що національна свідомість на Україні справді дуже зросла, та що боротьба за самостійність України дійсно національна боротьба». Повідомлялося про обіцянку керівництвом ЧСР надати «Шульгинови всю поміч в Женеві і взагалі». На зустрічі пролунало питання про ставлення уряду УНР до Галичини. За повідомленям С. Смаль-Стоцького, «Шульгин заявив, що Уряд У.Н.Р. ніколи не зрік ся Галичини - він сам читав належний акт - там трактуєть ся Галичину як справу, вирішенє якої залежить від міжнародних чинників. Україна стоїть на становищі соборности. ... I Масарик і Бенеш приняли сю заяву Шульгина з найбільшим вдоволенєм з притиском, що між поодинокими частями України треба доконче порозуміння» [ЦДАВО України. Ф. 4440. Оп. 1. Спр. 16. Арк. 9-10].

Дещо по іншому повідомляв про цю аудієнцію О. Шульгин. Він інформував міністра закордонних справ УНР А. Ніковського, що у питанні про відносини з Польщею, «Я вияснив чому саме цей союз був необхідним і неминучим. Опозиції я не зустрів, навпаки п. Masaryk сказав, що «ми також хочемо полагодити відношення з поляками» [Піскун, 2016: 189-191]. О. Шульгин не згадує про обіцянки підтримки Прагою делегації УНР в Женеві, яка мала намір подати заявку на вступ до Ліги Націй [Бетлий, 2006: 141, 142].

Враховуючи вищезазначене, керівництво Чехословаччини не могло підтримати звернення представників ЗУНР від 24 жовтня 1920 р. про допомогу у створенні самостійної східногалицької держави та укладення нею союзу з ЧСР, УНР, Білоруссю, Литвою і Естонією [Карпенко, 2011: 269-276]. Це саме стосувалося й листа $€$. Петрушевича президенту Чехословаччини від 30 грудня 1920 р. $з$ проханням підтримати ідею створити з інтернованих українських частин «сильну і боєздатну військову організацію ...., яка в разі потреби змогла би станути поруч Чехословацьких полків у боях за цілість Чеської і визволення Галицької Української Республіки». Для цього, зокрема, пропонувалося поповнення «українського-галицького леґіону» українськими військовими-емігрантами із сусідніх країн та Закарпаття [Карпенко, 2008: 747-749].

Вже у період підготовки і укладення Ризького миру 1921 р. керівництво ЧСР прагнуло нормалізувати відносини 3 Польщею [Нагорняк, 2000: 280]. Наступні повідомлення С. СмальСтоцького засвідчують зміну ставлення вищого керівництва ЧСР до українського питання. У цей час Я. Нечас підготував Т. Ґ. Масарику реферат із зазначеної проблеми [Карпенко, 2011: 496]. Згідно листа голови представництва ЗУНР, Я. Нечас говорив йому про своє незадоволення розмовою з президентом ЧСР 27 січня 1921 р. «Масарик, каже, все ще стоїть на становищі великої сфредералізованої Росії, а в яку небудь самостійність України, ну очевидно ще тим 
меньше Східної Галичини йому неконечно хочеть ся вірити. ... ». При цьому слушно зауважувалося, що вони збігаються 3 поглядами президента на впорядкування «старого континенту» після світової війни, висловленими у його книзі «Нова Європа. Слов'янська точка зору» (1918р.). С. Смаль-Стоцький водночас висловив думку, що «з Масариком можна говорити і дійти до порозуміня. ... » [ЦДАВО України. Ф. 4440. Оп. 1. Спр. 16. Арк. 32]. У зв'язку з цим, 7 лютого 1921 р. С. Смаль-Стоцький надіслав К. Левицькому нарис О. І. Бочковського про книгу Т. Ґ. Масарика «Нова Європа» [ЦДАВО України. Ф. 4440. Оп. 1. Спр. 16. Арк. 43].

Втім, спроби західноукраїнського дипломата вплинути на керівництво ЧСР за допомогою публікації у чеській пресі матеріалів про Україну, були невдалими. Так, на інспіровану ним в одній із чеських газет нотатку "Самостійність Східної Галичини визнана під протекторатом Малої Антанти», видання «С̌as», що знаходилося під впливом Е. Бенеша, заперечило таку можливість [ЦДАВО України. Ф. 4440. Оп. 1. Спр. 16. Арк. 25].

Також С. Смаль-Стоцькому не вдалося організувати візит $€$. Петрушевича до президента ЧСР. Щоправда на заваді цього стали об'єктивні обставини - важке захворювання президента ЧСР, про яке С. Смаль-Стоцький неодноразово повідомляв у січні - квітні 1921 р. Уповноважненого для закордонних справ ЗУНР [ЦДАВО України. Ф. 4440. Оп. 1. Спр. 16. Арк. $27,36,46,55,67-67$ зв, 89].

У документах представників ЗУНР не аналізувалося ставлення Т. Ґ. Масарика до Закарпаття, але згадуються окремі аспекти перебування краю у складі ЧСР та, зокрема, постать його першого губернатора. У листі від 13 квітня 1921 р. про аудієнцію губернатора Закарпаття Г. Жатковича у Т. Ґ. Масарика, висловлювалося переконання про неприйняття його відставки 3 посади. Відставку С. Смаль-Стоцький вважав некорисною для українських інтересів: «Жаткович боронить автономії Прикарпатської Руси до крайности і в послідних часах відносив ся до укр. руху вже далеко прихильнійше ніж перше» [ЦДАВО України. Ф. 4440. Оп. 1. Спр. 16. Арк. 86]. Але відставка відбулася 13 травня 1921 р. [Кравчук, 2008: 111]. 7 серпня 1921 р. С. СмальСтоцький доповідав, що «Перед своїм від'їздом до Америки Др. Жаткович мав не тільки щиру розмову зі мною, але і публичний виклад про Прикарпатську Русь і свої заходи в справі її автономії і управильнення границь супроти Словаччини. ... ». Також повідомлялося, що Г. Жаткович «Прикарпатських Русинів в Америці ... до одного змобілізує до боротьби за повну, як найповнішу автономію та етнографрічні границі. ... » [ЦДАВО України. Ф. 4440. Оп. 1. Спр. 16. Арк. 118 зв.].

У зв'язку з цим відзначимо, що у листі від 16 грудня 1920 р. С. Смаль-Стоцький позитивно оцінював працю емігрантів із Галичини у Закарпатті на посадах суддів і вчителів, відзначав шанобливе ставлення до них місцевого населення [ЦДАВО України. Ф. 4440. Оп. 1. Спр. 16. Арк. 17-18]. Також варто згадати звернення $€$. Левицького до Т. Ґ. Масарика від 1 березня 1922 р. із проханням про захист біженців. Він критикував циркуляр міністерства внутрішніх справ від 30 грудня 1921 р. про реєстрацію емігрантів. Застосування цього документу загрожувало депортацією до Польщі емігрантів, які працювали в Закарпатті. Серед аргументів, Є. Левицький відзначає невизначеність на той час міжнародно-правового статусу Східної Галичини [Doubek, 2016: 140-143.; Топінка, 2010: 124-129]. Незважаючи на відсутність відповіді на цей лист, лояльним до ЧСР емігрантам була забезпечена можливість працювати на Закарпатті, де вони зробили чимало для розвитку регіону.

Загалом, повністю реалізувати свої прагнення дипломати ЗУНР не змогли. У контексті курсу Антанти на повоєнного врегулювання у Центрально-Східній Європі, що включало підтримку Польщі, та й зацікавленістю самої ЧСР у покращенні відносин з Варшавою, Прага не могла допомогти емігрантському уряду ЗУНР у відродженні державності. Позиція ЧСР в українському питанні значною мірою визначалася політикою Антанти. Враховуючи ії рішення щодо Східної Галичини у березні 1923 р., Прага відмовила Є. Петрушевичу у проханні емігрувати до ЧСР.

30 квітня 1923 р. еміграційний уряд $€$. Петрушевича у Відні припинив свою діяльність як, незабаром й представництво ЗУНР у Празі [Павлишин, 2013: 302]. Табори інтернованих військових Української Галицької армії було розформовано. Приблизно 3 тис. колишніх стрільців залишилися в ЧСР, навчалися в чеських та українських емігрантських вищих навчальних закладах [Кірсенко, 2006: 56]. Після завершення навчання українських біженців, емігрантські освітні заклади припинили діяльність. Лише один із них - Український вільний університет вдалося зберегти завдяки фінансовій підтримці президента ЧСР Т. Ґ. Масарика [Кравчук, 2019: 196]. Нині цей заклад функціонує у Мюнхені.

Висновки. Документи представництва ЗУНР у Празі висвітлюють позицію Т. Ґ. Масарика щодо українського питання у контексті встановлення відносин між ЧСР і ЗУНР наприкінці 1918 на початку 1919 рр., прагнення представників останньої здобути підтримку Праги у забезпеченні визнання країнами Антанти державної самостійності. Документи представництва ЗУНР $€$ важливим джерелом вивчення історії чехословацько-українських відносин та сприйняття постаті 
президента ЧСР дипломатами ЗУНР. Необхідно продовжити вивчення контактів представників чехословацької влади з представниками ЗУНР, використовуючи архівні документи Чеської Республіки, матеріали чеської періодики тощо.

Подяка. Висловлюю щиру вдячність членам редакційної колегії журналу за конструктивні консультації, надані під час підготовки статті до друку.

Фінансування. Автор не отримав фрінансової підтримки для проведення дослідження й публікації цієї статті.

\section{Джерела та література:}

Бетлий, О. (2006). Украина 1919-1923: пражский проект. Европа. Журнал польского института международных дел, Т. 6. № 2 (19), С. 119-151.

Бочковський, [О. І.] (1930) Із спогадів про Т. Г. Масарика. Тризуб, Ч. 36, 28 вересня, С. 12-14.

Віднянський, С. В. (1997) Українське питання в зовнішньополітичних концепціях Чехословаччини (1918-1989рр.). Український історичний журнал, № 1, С. 43-61.

Галицька-Дідух, Т. В. (2015) Східногалицька проблема як об'єкт міжнародної політики (січеньсерпень 1920 р.). Гілея. Науковий вісник. Зб. наук. пр., Вип. 101 (№ 10), С. 33-42.

Григориїв, Н. (1941). Т. Ґ. Масарик та українці. Народна воля, Ч. 28, 11 березня, С. 2.

Історичні постаті Галичини XIX - XX ст. (1961), Ню Йорк-Париж-Сідней-Торонто: Заходом і коштом Осередку праці НТШ у Філядельфії, 247 с.

Карпенко, О. (ред.). (2001). Західно-Українська Народна Республіка 1918-1923. Документи і матеріали. У 5 т. Т. 2. Державотворчі й адміністративно-організаційні процеси), ІваноФранківськ: Лілея-НВ, 712 с.

Карпенко, О. (ред.). (2008). Західно-Українська Народна Республіка 1918-1923. Документи і матеріали. У 5 т. Т. 4. Збройні сили у боротьбі за свободу, незалежність, соборність / Укладачі: О. Карпенко, К. Мицан, Івано-Франківськ: Лілея-НВ, 886 с.

Карпенко, О. (ред.). (2011). Західно-Українська Народна Республіка 1918-1923. Документи і матеріали. У 5 т. Т. 5. Кн. 2. Зовнішня політика і міжнародне становище. 1920-1921рр. / Укладачі: О. Карпенко, К. Мицан, Івано-Франківськ: Місто НВ, 948 с.

Кірсенко, М. В. (2006). ЗУНР і політика Чехословаччини. Наукові записки Національного університету «Києво-Могилянська академія». Історичні науки, Вип. 52, С. 53-57.

Кравчук, О. (2019). Роль Т. Ґ. Масарика у наданні допомоги українській еміграції в Чехословацькій республіці. Дриновський збірник. Софрія-Харків, Т. 12, С. 188-201. DOI: https://doi.org/10.7546/DS.2019.12.21

Кравчук, О. М. (2008). Національна політика Чехословацької республіки. 1918-1929 рр. Вінниця: Едельвейс, 248 с.

Литвин, Н. М. (2012). Взаємини еміграційного уряду ЗУНР із країнами Центрально-Східної Європи. Гілея. Науковий вісник. Зб. наук. пр., Вип. 61 (№ 6), С. 620-625.

Нагорняк, М. (2000). Українське питання в зовнішньополітичній доктрині Т. Г. Масарика. Україна: культурна спадщина, національна свідомість, державність, Львів, Вип. 6, С. 277-281.

Павлишин, О. (2013). Євген Петрушевич (1863-1940). Ілюстрований біографрічний нарис, Львів: Манускрипт-Львів, 400 с.

Павлюк, О. (1997). Зовнішня політика ЗУНР. Київська старовина, № 3/4, С. 114-138.

Піскун, В. (ред.). (2016). Олександр Шульгин в українському державотворенні та міжнародній політиці / Збірник наукових праць та документів, Київ: Інститут української археографії та джерелознавства ім. М. С. Грушевського НАН України, 432 с.

Топінка, $\boldsymbol{\epsilon}$. (ред.). (2010). Томаш Масарик і українці. Архівні документи, Львів: «Видавництво «Центр Європи», 440 с.

ЦДАВО України - Центральний державний архів вищих органів влади та управління України.

Цегельський, Л. (1960). Від леґенд до правди. Нью-Йорк-Филадельфрія: Видавництво «Булава», $313 \mathrm{c}$.

Doubek V. (Ed.). (2016). Korespondence T. G. Masaryk - Slované. Rusové a Ukrajinci. (2. svazek, Praha: Masarykův ústav a Archiv AV ČR, $736 \mathrm{~s}$.

Hájkova D., Quagliatová V. \& Vašek R. (Ed.). (2013). Korespondence T. G. Masaryk - Edvard Beneš 1918-1937. Praha: Masarykův ústav a Archiv AV ČR, v. v. i., 484 s.

Harbul'ová, L. (2013) T. G. Masaryk - ukrajinská otázka - ukrajinskí politíckí predstavitelia (19171920). T. G. Masaryk a Slované, Praha: Historický ústav AV ČR, v. v. i. a Masarykův ústav a Archiv AV ČR, v. v. i., S. 101-110. 


\title{
Александр Кравчук
}

Винницкий государственный педагогический университет имени Михаила Коцюбинского кандидат исторических наук, доцент (Украина)

\section{Т. Г. Масарик и украинский вопрос в документах представительства Западноукраинской Народной Республики в Праге}

Аннотация. Цель статьи - проанализировать сообщения представительства ЗУНР в Праге об отношении президента Чехословакии Т. Г. Масарика к украинскому вопросу. Методология исследования основывается на научно-исследовательских принципах историзма, научности, объективности, общих научных методах (источниковедческого анализа, исторического и логического) и специальных исторических методах (нарративном и проблемно-хронологическом). Научная новизна работы состоит в том, что в статье на основе архивных и опубликованных материалов, в частности, писем глав представительства Западноукраинской Народной Республики в Праге к руководителям внешнеполитического ведомства указанного государственного образования, анализируется отношение первого президента Чехословакии к украинскому вопросу. Выводы. Отношение T. Г. Масарика к украинскому вопросу рассматривается в контексте установления отношений между Чехословакией и Западноукраинской Народной Республикой в конце 1918 в начале 1919 ге., стремления представителей последней в 1920-1923 г2. получить поддержку Праги в обеспечении признания странами Антанты самостоятельности этого государства, обсуждения вопроса помощи украинским эмигрантам в чСР. Отмечено изменения позиции президента ЧСР в украинском вопросе. В работе «Новая Европа» (1918 г.) он поддерживал идею объединения Надднепрянщины, Восточной Галиции и Буковины в единую украинскую автономию $u$ ее пребывание в составе фредеративного демократического российского государства. В начале 1919 2. президент чСР был готов признать независимость Украинской Народной Республики, которая возродилась во время восстания против гетмана. Но окончательное решение он ставил в зависимость от позиции государств Антанты на мирной конференции в Париже. Освещение представителями ЗУНР в Праге восприятия украинского вопроса Т. Г. Масариком в 19201921 ге. свидетельствует о его возвращении к концепции, изложенной в работе «Новая Европа». Сообщения представителей ЗУНР позволяют более полно изучить обстоятельства, которые сделали невозможным получение ею политической поддержки со стороны Чехословакии. Учитывая это, а также поднятые в отчетах представительства вопросы политики ЧСР в Закарпатье и относительно эмиграции, указанные документы являются важным источником изучения истории чехословацко-украинских отношений.

Ключевые слова: дипломатия, Е.Левицкий, Е. Петрушевич, Закарпатье, Западноукраинская Народная Республика, С. Смаль-Стоцкий, Т. Г. Масарик, Чехословацкая республика, эмигранты.

\section{Oleksandr M. Kravchuk \\ Vinnytsia Мукhailo Kotsiubinskyi State Pedagogical University PhD (History), Associate Professor (Ukraine)}

\section{T. G. Masaryk and the Ukrainian Question in the Documents of the Representation of the Western Ukrainian People's Republic in Prague}

\begin{abstract}
The purpose of the article is to analyze the representation's report of the Western Ukrainian People's Republic in Prague on the attitude of the president of Czechoslovakia T. G. Masaryk to the Ukrainian question. The research methodology is based on the research principles of historicism, scientificity, objectivity, general scientific methods (source analysis, historical and logical) and special historical methods (narrative and problem-chronological). The scientific novelty of the work is that the article on the basis of archival and published materials, in particular, the letters of the heads of the representation of the Western Ukrainian People's Republic in Prague to the foreign ministers of the state, analyzes the attitude of the first president of Czechoslovakia to the Ukrainian question. Conclusions. Masaryk's attitude to the Ukrainian question is considered in the context of establishing relations between Czechoslovakia and the Western Ukrainian People's Republic in late 1918 - early 1919, the desire of ones in 1920-1923 to gain the support of Prague in ensuring the recognition of the Entente countries the independence of this state, discussion of the case of assisting for Ukrainian emigrants in Czechoslovakia. In the article were noted the changes in the position of the Czechoslovak president in the Ukrainian question. In his work «New Europe» (1918), he supported the idea of the uniting of the Dnieper region, Eastern Galicia and Bukovina considering it necessary to
\end{abstract}


preserve it as part of the federal democratic Russian state. In early 1919 president of the Czechoslovak Republic was ready to recognize the independence of the Ukrainian People's Republic, which was revived during the anti-Hetman uprising. But made the final decision dependent on the position of the Entente states at the peace conference in Paris. The coverage of the perception of the Ukrainian question by T. G. Masaryk in 1920-1921 by the representatives of the Western Ukrainian People's Republic in Prague testifies to his return to the concept set forth in the work «New Europe». Reports from representatives of the Western Ukrainian People's Republic allow a more complete study of the circumstances that made it impossible for it to gain political support from Czechoslovakia. Given this, as well as the issues of the Czechoslovak Republic's policy in Transcarpathia and on emigration were raised in the reports of the representation, these documents are an important source for studying the history of Czechoslovak-Ukrainian relations.

Key words: Czechoslovak Republic, diplomacy, Ye. Levytsky, Ye. Petrushevych, emigrants, S. Smal-Stotsky, T. G. Masaryk, Transcarpathia, Western Ukrainian People's Republic.

\section{References:}

Betlij, O. (2006). Ukraina 1919-1923: prazhskiy proekt [Ukraine 1919-1923: Prague project]. Yevropa. Zhurnal polskogo instituta mezhdunarodnykh del - Journal of the Polish Institute of International Affairs, T. 6, № 2 (19), 119-151. [In Russian]

Bochkovsky, [O. I.] (1930). Iz spogadiv pro T. G. Masaryka [From memories about T. G. Masaryk]. Tryzub - Trident, Ch. 36, 28 veresnya, 12-14. [In Ukrainian]

Cehelsky, L. (1960). Vid legend do pravdy [From legends to facts]. New York- Philadelphia: Vydavnyctvo «Bulava», $313 \mathrm{~s}$. [In Ukrainian]

Doubek V. (Ed.) (2016). Korespondence T. G. Masaryk - Slované. Rusové a Ukrajinci [Correspondence of T. G. Masaryk and Slavs. Russians and Ukrainians]. (2. svazek, Praha: Masarykův ústav a Archiv AV ČR, 736 s. [in Czech; in Russian; in Ukrainian]

Hájkova D., Quagliatová V. \& Vašek R. (Ed.). (2013). Korespondence T. G. Masaryk - Edvard Beneš 1918-1937 [Correspondence of T. G. Masaryk - Edvard Beneš 1918-1937]. Praha: Masarykův ústav a Archiv AV ČR, v. v. i.., 484 s. [in Czech]

Halytska-Didukh, T. V. (2015.). Skhidnoghalyc'ka problema jak ob'jekt mizhnarodnoji polityky (sichen'-serpen' 1920 r.) [The Eastern-Galician problem as the object of international policy (January August 1920)]. Hileya. Naukovyj visnyk. Zb. nauk. pr. - Hileya. Scientific herald. Collection of scientific papers, Vyp. 101 (№ 10), 33-42. [In Ukrainian]

Harbul'ová, L. (2013) T. G. Masaryk - ukrajinská otázka - ukrajinskí politíckí predstavitelia (19171920) [T. G. Masaryk, the Ukrainian Question and Ukrainian Political Representatives (1917-1920)]. T. G. Masaryk a Slované [T. G. Masaryk and the Slavs], Praha: Historický ústav AV ČR, v. v. i. a Masarykův ústav a Archiv AV ČR, v. v. i., 101-110. [in Slovak]

Hryhoryjiv, N. (1941). T. G. Masaryk ta ukrajinci [T. G. Masaryk and Ukrainians]. Narodna volja People's will, Ch. 28, 11 bereznja, 2. [In Ukrainian]

Istorychni postati Ghalychyny XIX - XX st. [Historical personages of Galicia in XIX - XX cent.] (1961). New York-Paris-Sydney-Toronto: Zakhodom i koshtom Oseredku praci NTSh u Filjadel'fii, 247 s. [In Ukrainian]

Karpenko, O. (Ed.). (2001). Zakhidno-Ukrajinsjka Narodna Respublika 1918-1923. Dokumenty i materialy [Western Ukrainian People's Republic 1918-1923. Documents and materials], U 5 t. T. 2. Derzhavotvorchi j administratyvno-orghanizacijni procesy [State-building and administrativeorganizational processes], Ivano-Frankivsk: Lileia-NV, 712 s. [In Ukrainian]

Karpenko, O. (Ed.). (2008). Zakhidno-Ukrajinsjka Narodna Respublika 1918-1923. Dokumenty i materialy [Western Ukrainian People's Republic 1918-1923. Documents and materials], U 5 t. T. 4. Zbrojni syly u borot'bi za svobodu, nezalezhnist', sobornist'[Armed forces in the struggle for freedom, independence, unity], O. Karpenko, K. Mytsan (Comps.), Ivano-Frankivsk: Lileia-NV, 886 p. [In Ukrainian]

Karpenko, O. (Ed.). (2011). Zakhidno-Ukrajinsjka Narodna Respublika 1918-1923. Dokumenty i materialy [Western Ukrainian People's Republic 1918-1923. Documents and materials], U 5 t. T. 5. Kn. 2. Zovnishnja polityka i mizhnarodne stanovyshhe. 1920-1921 rr. [Foreign policy and international situation. 1920-1921], O. Karpenko, K. Mytsan (Comps.), Ivano-Frankivsk: Misto NV, 948 p. [In Ukrainian]

Kirsenko, M. V. (2006). ZUNR i polityka Chekhoslovachchyny [West Ukrainian National Republic and the Czechoslovak policy]. Naukovi zapysky Nacional'nogo universytetu "Kyjevo-Mohyljans'ka akademija». Istorychni nauky - National University of Kyiv-Mohyla Academy Research Papers. History, Vyp. 52, 53-57. [In Ukrainian]

Kravchuk, O. (2019). Rol' T. G. Masaryka u nadanni dopomoghy ukrajins'kij emighraciji v Chekhoslovacz'kij respublici [The role of T. G. Masaryk in assisting of Ukrainian emigration in the 
Czechoslovak republic]. Drynovs'kyj zbirnyk - Drinov's collection. Sofija-Kharkiv, T. 12, 188-201. DOI: https://doi.org/10.7546/DS.2019.12.21 [In Ukrainian]

Kravchuk, O. M. (2008). Nacionaljna polityka Chekhoslovacz'koji respubliky. 1918-1929 rr. [National policy of the Czechoslovakian Republic. 1918 - 1929]. Vinnytsia: Edeljvejs, 248 s. [In Ukrainian]

Lytvyn, N. M. (2012). Vzajemyny emighracijnogho urjadu ZUNR iz krajinamy Central'no-Skhidnoji Yevropy [Mutual relations of emigratory government of West Ukrainian National Republic with the Central Eastern European countries]. Hileya. Naukovyj visnyk. Zb. nauk. pr. - Hileya. Scientific herald. Collection of scientific papers, Vyp. 61 (№ 6), 620-625. [In Ukrainian]

Nagornyak, M. (2000). Ukrajins'ke pytannja v zovnishn'opolitychnij doktryni T. G. Masaryka [The Ukrainian question in the foreign policy doctrine of T. G. Masaryk]. Ukrajina: kul'turna spadshhyna, nacional'na svidomist', derzhavnist' - Ukraine: Cultural Heritage, National Identity, Statehood. Lviv, (Vyp. 6), 277-281. [In Ukrainian]

Pavliuk, O. (1997). Zovnishnja polityka ZUNR [Foreign policy of the Western Ukrainian People's Republic]. Kyivs'ka starovyna - Kyiv antiquity, (№ 3/4), 114-138. [In Ukrainian]

Pavlyshyn, O. (2013). Yevhen Petrushevych (1863-1940). I'ustrovanyj bioghrafichnyj narys [Yevhen Petrushevych (1863-1940). Illustrated Bibliography Sketch], Lviv.: Manuskrypt-Lviv, 400 s. [In Ukrainian]

Piskun V. (Ed.). (2016). Oleksandr Shul'gyn v ukrayins'komu derzhavotvorenni ta mizhnarodnij polityci / Zbirnyk naukovykh pracz ta dokumentiv [Oleksandr Shulhyn in the Ukrainian State Building and International Politics / Collection of Scientific Works and Documents], Kyiv: Instytut ukrajinsjkoji arkheoghrafiji ta dzhereloznavstva im. M. S. Ghrushevsjkogho NAN Ukrajiny, 432 s. [In Ukrainian] Topinka, Ye. (Ed.). (2010). Tomash Masaryk i ukrajinci. Arkhivni dokumenty [Tomash Masaryk and Ukrainians. Archival documents]. Lviv: «Vydavnycztvo «Centr Yevropy», 440 s. [In Ukrainian]

TsDAVO Ukrainy. - Tsentral'nyj derzhavnyj arkhiv vyschykh orhaniv vlady ta upravlinnia Ukrainy The Central State Archives of Supreme Authorities and Governments of Ukraine. [in Ukrainian].

Vidnyanskyy, S. V. (1997). Ukrajins'ke pytannya V zovnishnjopolitychnykh koncepcijakh Chekhoslovachchyny (1918-1989 rr.) [The Ukrainian question in the foreign policy concepts of Czechoslovakia (1918-1989)]. Ukrajins'kyj istorychnyj zhurnal. - Ukrainian Historical Journal, № 1, 4361. [In Ukrainian] 